\title{
THE FREQUENCY OF SYMPTOMS OF COMPUTER VISION SYNDROME AMONG MEDICAL COLLEGE STUDENTS IN ISLAMABAD.
}

1. MBBS, MPH

Senior Lecturer Community Medicine and Public Health

Foundation University Medical College Islamabad.

Correspondence Address:

Dr. Shumaila Humayun

Senior Lecturer Community Medicine and Public Health

Foundation University Medical College Islamabad.

shumailahn@gmail.com

Article received on: 14/10/2019 Accepted for publication: 03/02/2020

\begin{abstract}
Shumaila Humayun ${ }^{1}$
ABSTRACT... Objectives: Indiscriminate use of computers has increased during the present fast-paced age, and this technology misuse has negatively affected many users. This study aimed to determine the presence of the symptoms of computer vision syndrome and to assess the pattern of computer usage in medical college students. Study Design: Descriptive Crosssectional study. Settings: Foundation University Medical College, Islamabad, among the MBBS students. Period: From March till August 2018. Material \& Methods: A total of 240 conveniently selected medical students took part in this cross-sectional study and filled a pretested selfadministered questionnaire, during a six month duration. Ethical consideration was taken, and unwilling students or those with ocular, muscular and general diseases were excluded. Results: A majority of participants $181(75.4 \%)$ were females, rest $24.58 \%$ were males. The mean age was 21 yrs with SD of $1.6 \mathrm{yrs}$. A dominant number,170 (70.8\%) experienced sore/ strained eyes followed by watering of eyes,128 ( $53.3 \%$ ), and blurred distant vision,121 (50.4\%), pain $42.9 \%$,redness $40.8 \%$, dryness $33.8 \%$, blurred near vision $29.2 \%$, burning eyes sensation $42.9 \%$,twitching of eyelids $35 \%$, double vision $24.2 \%$. Headache was experienced by178 ( $74.2 \%)$ participants, followed by backache in $137(57.1 \%)$ students, due to overuse of computer(significant at a $p$ value of 0.01 ).About $62.5 \%$ were not using antiglare screens, or frequent blinking method (56.7\%) as a means of protection. Conclusion: A majority of the study population had been using computers for less than $5 \mathrm{yrs}$, giving adequate breaks during the day, yet they were experiencing symptoms of CVS like sore/strained eyes and headache as a consequence of regular computer usage. Most of them were not taking protective measures during computer work.
\end{abstract}

Key words: $\quad$ Antiglare Screens, Computer, Cross-Sectional, Syndrome, Vision.

Article Citation: Humayun S. The frequency of symptoms of computer vision syndrome among medical college students in Islamabad. Professional Med J 2020; 27(9):1823-1828. DOI: 10.29309/TPMJ/2020.27.09.3967

\section{INTRODUCTION}

In the present fast age of technology, our lives have become dependent on computer usage and unlimited access to electronic devices like smartphones, tablets, etc., whether it is related to our work, in educational institutes, or for entertainment purposes. ${ }^{1}$ The continued and unchecked usage has posed a danger to our health and an escalated risk for Computer Vision Syndrome (CVS). ${ }^{2}$ CVS is defined as a group of vision, ocular and extra-ocular symptoms which are related to continuous usage of visual display units. Most of these symptoms are related to eye vision, eye muscles, light sensitivity, musculoskeletal system and other general body symptoms. ${ }^{3}$ Around $64 \%-90 \%$ of people experience these symptoms due to overuse and indiscriminate use of computers. ${ }^{4}$ Worldwide approximately 60 million people suffer from CVS. ${ }^{5}$ The incidence of new cases each year mounts to a million. ${ }^{5}$

According to studies done in developed countries like America, Spain and Australia, this problem is estimated to affect $90 \%, 68.5 \%$ and $63.4 \%$ people respectively. Whereas in India around $46.3 \%$ are affected. ${ }^{6}$

The most commonly experienced symptoms of CVS are strain on eyes, blurring of vision, dryness of eyes, headache neck and shoulder pain. ${ }^{6,7}$ The resulting unease and discomfort due to increased 
usage of computers might not permanently harm the individual but it may decrease the accuracy of his work and productivity by $40 \%{ }^{8}$ The eye related symptoms even of mild to moderate intensity can reduce the efficiency of many personal activities and tasks performed by the individual. ${ }^{6}$ The best way is the $20 / 20$ rule, giving a break of 20 min after every 20 min to avoid strain and to divert the gaze of eyes to a different direction or object. ${ }^{7}$

Various studies on this matter have been conducted throughout the world, and relation between computer overuse, bad sitting posture, and inappropriate position and light has been studied, but they are mainly on western people. ${ }^{5}$

The main purpose of this study was to highlight the frequency of symptoms associated with Computer Vision syndrome among medical college students in order to create awareness regarding CVS in the study population. Since no study on this topic has been conducted in Islamabad, this study will fill the identified knowledge gap. The findings of our study will be a valuable addition to the body of knowledge, and help in designing strategies for better usage practices regarding computers.

\section{Objectives}

1. To assess the frequency of symptoms associated with computer vision syndrome among the study population.

2. To determine the computer usage pattern of medical college students.

\section{MATERIAL \& METHODS}

This was a descriptive cross-sectional study conducted on all students of MBBS at Foundation University Medical College, Islamabad (FUMC) from March till August 2018.

The Sample Size was 240 and the Sampling Technique used was Convenience sampling.

Data was collected using self-administered pretested structured questionnaire. The tool was adapted and modified from a previous study (Ergophthalmology in accounting offices: the computer vision syndrome (CVS) by Arjuna Nudi
Perin, Dyonathan Fernande Bonamigo, Marcello de Quadros Ribeiro, Ricardo Alexandre Stock, Aline Pertile Remor, Diego de Carvalho, Jovani Antônio Steffani, Elcio Luiz Bonamigo- Rev Bras Oftalmol. 2017; 76 (3): 144-9)

\section{Inclusion Criteria}

All MBBS students studying in Foundation University Medical College having used computer, phone, tablet or such gadgets within the past 1 month.

\section{Exclusion Criteria}

Any student having any injury/accident to eye, or diagnosed with hypertension, diabetes, eye disease, musculoskeletal illness, and any student not willing to participate in this study.

Data was analyzed using SPSS 21 , and results were mainly presented as frequencies and percentages and shown in graphic form as bar charts, pie charts and frequency tables.

Written informed consent was obtained from all the participants. The confidentiality of participants was maintained. Taking part in this research was entirely voluntary and they were allowed to withdraw from research at any stage. Permission was taken from the Ethical Review Committee of FUMC.

\section{RESULTS}

A total of 240 students participated in this study. The age range of the students was 17-26 yrs. A majority $181(75.4 \%)$ of them were females, rest $24.58 \%$ were males.

Among the ocular symptoms, the most frequently observed was sore/strained eyes in 170 (70.8\%) followed by watering of eyes in 128 (53.3\%), and blurred distant vision in $121(50.4 \%)$ respondents.

Among the extra-ocular symptoms most common was headache in 178 (74.2\%) followed by backache in $137(57.1 \%)$ students.

Around $9.8 \%$ used desktop personal computer, and $37.9 \%$ used laptops, while a majority (52.3\%) of them used other handheld devices. 


\begin{tabular}{|l|c|}
\hline \multicolumn{1}{|c|}{$\mathbf{N}$} & $\mathbf{2 4 0}$ \\
\hline Mean & 21 \\
\hline Standard Deviation & 1.64 \\
\hline Minimum & 17 \\
\hline Maximum & 26 \\
\hline \multicolumn{2}{|c|}{ Table-I. Mean age of the respondents (in years). } \\
\hline
\end{tabular}

\begin{tabular}{|c|c|c|c|}
\hline \multicolumn{2}{|c|}{ Eye Symptoms } & \multirow{2}{*}{$\begin{array}{c}\text { Frequency } \\
98\end{array}$} & \multirow{2}{*}{$\begin{array}{c}\text { Percentage } \\
\% \\
40.8\end{array}$} \\
\hline Redness of & Yes & & \\
\hline eyes & No & 142 & 59.2 \\
\hline \multirow{2}{*}{$\begin{array}{l}\text { Blurred near } \\
\text { vision }\end{array}$} & Yes & 70 & 29.2 \\
\hline & No & 170 & 70.8 \\
\hline \multirow{2}{*}{$\begin{array}{l}\text { Blurred distant } \\
\text { vision }\end{array}$} & Yes & 121 & 50.4 \\
\hline & No & 119 & 49.6 \\
\hline \multirow{2}{*}{ Dry eyes } & Yes & 81 & 33.8 \\
\hline & No & 159 & 66.3 \\
\hline \multirow{2}{*}{$\begin{array}{l}\text { Burning eye } \\
\text { sensation }\end{array}$} & Yes & 103 & 42.9 \\
\hline & No & 137 & 57.1 \\
\hline \multirow{2}{*}{ Double vision } & Yes & 58 & 24.2 \\
\hline & No & 182 & 75.8 \\
\hline \multirow{2}{*}{$\begin{array}{l}\text { Twitching of eye } \\
\text { lids }\end{array}$} & Yes & 84 & 35 \\
\hline & No & 156 & 65 \\
\hline \multirow{2}{*}{$\begin{array}{l}\text { Changes in } \\
\text { visualizing } \\
\text { colours }\end{array}$} & Yes & 46 & 19.2 \\
\hline & No & 194 & 80.8 \\
\hline \multirow{2}{*}{$\begin{array}{l}\text { Watering of } \\
\text { Eyes }\end{array}$} & Yes & 128 & 53.3 \\
\hline & No & 112 & 46.7 \\
\hline \multirow{2}{*}{$\begin{array}{l}\text { Pain in and } \\
\text { around the eyes }\end{array}$} & Yes & 103 & 42.9 \\
\hline & No & 137 & 57.1 \\
\hline \multirow{2}{*}{$\begin{array}{l}\text { Sore/strained } \\
\text { eyes }\end{array}$} & Yes & 170 & 70.8 \\
\hline & No & 70 & 29.2 \\
\hline
\end{tabular}

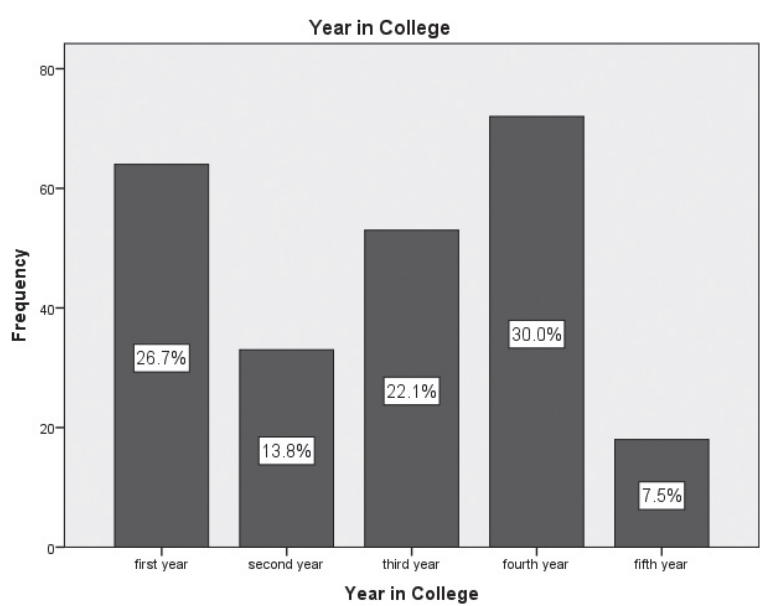

Figure-1. Year in college of the respondents.

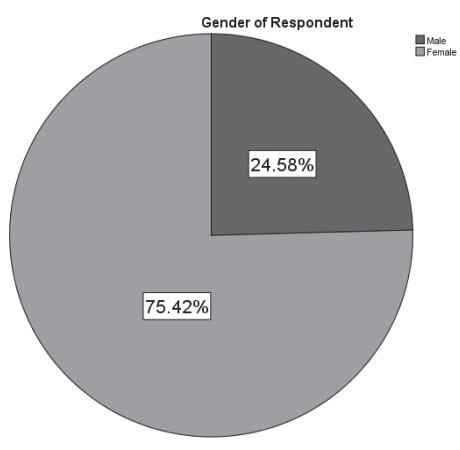

Figure-2. Gender of the respondents.

\begin{tabular}{|l|c|c|c|}
\hline $\begin{array}{c}\text { Extra-ocular } \\
\text { Symptoms }\end{array}$ & Response & Frequency & $\begin{array}{c}\text { Percentage } \\
\%\end{array}$ \\
\hline \multirow{2}{*}{ Headache } & Yes & 178 & 74.2 \\
\cline { 2 - 4 } & No & 62 & 25.8 \\
\hline \multirow{2}{*}{ Backache } & Yes & 137 & 57.1 \\
\cline { 2 - 4 } & No & 103 & 42.9 \\
\hline
\end{tabular}

Table-III. Extra- ocular symptoms among students after computer usage.

\begin{tabular}{|c|c|c|c|}
\hline \multicolumn{2}{|c|}{ Computer Usage } & Frequency & Percentage \\
\hline \multirow{3}{*}{$\begin{array}{l}\text { Duration of } \\
\text { device usage } \\
\text { in years }\end{array}$} & Less than 5 years & 99 & 41.3 \\
\hline & $5-10$ years & 88 & 36.7 \\
\hline & More than 10 years & 53 & 22.1 \\
\hline \multirow{6}{*}{$\begin{array}{l}\text { Frequency of } \\
\text { breaks }\end{array}$} & Every 20 minutes & 88 & 36.7 \\
\hline & Every $1 \mathrm{hr}$ & 68 & 28.3 \\
\hline & Every 2 hrs & 25 & 10.4 \\
\hline & Every 3 hrs & 17 & 7.1 \\
\hline & More than 3 hrs & 16 & 6.7 \\
\hline & No break & 26 & 10.8 \\
\hline \multirow{3}{*}{$\begin{array}{l}\text { Duration of } \\
\text { break }\end{array}$} & $<20$ minutes & 91 & 37.9 \\
\hline & $>20$ mins & 103 & 42.9 \\
\hline & none & 46 & 19.2 \\
\hline \multirow{3}{*}{$\begin{array}{l}\text { Device use in } \\
\text { hrs per day }\end{array}$} & $<3$ & 53 & 32.1 \\
\hline & $3-6$ & 132 & 55 \\
\hline & More than 6 hrs & 55 & 22.9 \\
\hline
\end{tabular}

Table-IV. Pattern of computer usage among students.

\begin{tabular}{|l|c|c|c|}
\hline \multicolumn{3}{|c|}{ Pearson's Chi-Square Test } \\
\begin{tabular}{|l|c|c|} 
Device usage \\
in years
\end{tabular} & Experiencing backache & $\begin{array}{c}\text { Asymp. Sig. } \\
\text { (2-sided) }\end{array}$ \\
\hline & yes & no & \\
\hline less than 5 years & 67 & 32 & \multirow{2}{*}{.019} \\
\hline $5-10$ yrs & 45 & 43 & \\
\hline$>10$ years & 25 & 28 & \\
\hline
\end{tabular}
A. 0 cells $(0.0 \%)$ have expected count less than 5 . The minimum expected count is $\mathbf{2 2 . 7 5}$. 
The application of Chi-square test shows that there is a significant association of the two variables i.e., backache and duration of computer usage in years, at $p<0.05$.

\begin{tabular}{|l|c|c|c|}
\hline Frequent blinking & Yes & 104 & $43.3 \%$ \\
\cline { 2 - 4 } during computer use & No & 136 & $56.7 \%$ \\
\hline $\begin{array}{l}\text { Usage of screen } \\
\text { protection or anti glare }\end{array}$ & Yes & 90 & $37.5 \%$ \\
\cline { 2 - 4 } screens & No & 150 & $62.5 \%$ \\
\hline
\end{tabular}

Table-VI. Preventive measures taken by students.

\section{DISCUSSION}

\section{Ocular Symptoms}

Our study was conducted amongst 240 medical college students of FUMC, Islamabad, where the response rate was 100 percent. The ages of respondents varied from 17-26 years with 21 years being the mean age. This statistic was almost consistent with studies carried amongst students of Karachi $^{9}$, Jamaica ${ }^{10}$ and Saudi Arabia; ${ }^{1}$ theirs being at 20,21 and 21 respectively.

Among the ocular symptoms, straining of eyes was reported with the highest frequency $(70.8 \%)$ followed by watering of eyes (53.3\%) which was in contrast to a study in Karachi, ${ }^{9}$ theirs being at $15 \%$ for strained eyes. This is surprising, given the similarity in the duration of device usage (3-6 hours); but the duration of break might play a relieving role, as majority of our students observed a break for about 20 minutes while theirs observed for more than 60 minutes.

The finding of eye strain as the most dominating symptom was consistent with studies in Jamaica $(67 \%)^{10}$ and Saudi Arabia(62.14\%), ${ }^{1}$ and may be a direct link to the increase in hours of usage for their majority, $>6$ hours/day for the former and $>8 \mathrm{hrs} /$ day for the latter.

The other symptoms (redness, dryness, pain etc) did not warrant a prevailing response and were, therefore, inconsequential.

Yet in another similar study in Saudi Arabia, dry eyes were reported by $51.5 \%$ of university students, which is quite high as compared to ours $(33.8 \%) .{ }^{12}$ While in a Sialkot study it was very close(32\%) to ours. On the contrary, straining of eyes was reported by $48 \%$ of Sialkot students, which was contrastingly higher in our students $(70.8 \%){ }^{13}$

According to Rosen field, the prevalence of dry eye symptoms is greater during computer operation probably because computer users blink less frequently leading to increased corneal exposure during constant work. ${ }^{14}$ This is evident from our study where $56.7 \%$ of the students do not blink frequently during computer use. CVS symptoms are associated with a reduced blink rate.

\section{Extra-Ocular Symptoms}

Among the extra-ocular symptoms the most common was headache $(72.4 \%)$ followed by backache $(57.1 \%)$. Headache was also found to be the most common extra- ocular symptom in studies conducted in Karachi $(38 \%)^{9}$ and in Malaysia (19.6\%) but in lower frequencies. ${ }^{10,11}$ This might be due to increased duration of breaks taken by their students.

In a study conducted in Malaysia only 54 (6.8\%) respondents experienced backache which is much lower than our finding (57.1\%). This might be attributed to decreased duration of computer usage in their students i.e majority $(27.1 \%)$ of the students used computer 1 hour daily, where the time range varied from $1-10$ hours, whereas $55 \%$ of our respondents used a device for 3-6 hours per day. ${ }^{11}$

A similar study on university students in Saudi Arabia revealed that headache was experienced by $66.5 \%$ of the students, resulting from computer usage of more than $5 \mathrm{hrs}$, which is in line with our findings for the same duration of computer usage. ${ }^{12}$ Results were in concordance with the Sialkot study, where headache was most common symptom (80\%), followed by backache (60\%). ${ }^{13}$

When it came to usage of protective measures like anti-glare screens, it was equally lacking i.e., $62.5 \%$ of our and $79.2 \%$ of students in Jamaican study never bothered to use it. ${ }^{10}$ In a similar study done in Kathmandu, Nepal, $34.3 \%$ of students had the habit of using antiglare screens for 
ocular protection. Also, it was found that frequent blinking was associated with reduced symptoms of CVS. ${ }^{15}$

The inevitable use of computers has led to feeling of discomfort during, and immediately after use and the presence of CVS has drastically decreased the quality of life and work productivity. ${ }^{16}$

It has specially affected performance of medical students as they are constant and frequent users. ${ }^{17}$ Hence in order to avoid trouble and to counteract its negative effects on health, there is need for increasing knowledge regarding accurate use of preventive measures regarding CVS among medical college students. ${ }^{18}$

\section{CONCLUSION}

The study concluded that a majority of the study population had been using computers for less than 5 years, and for a duration of 3-6 hrs per day giving $>20$ min break. A dominant majority of respondents were experiencing sore/strained eyes and headache as a consequence of regular computer usage. Majority of the respondents were not taking protective measures like frequent blinking or using antiglare screens during computer usage.

\section{Limitations}

- Study was limited due to shortage of time.

- Study was only performed in one university of Islamabad, and a small sample size was taken, hence it was not representative of the whole city.

- Convenience sampling was done so the results cannot be generalized.

\section{Recommendations}

- Study should be performed in larger samples.

- Health education about CVS should be increased by conducting campaigns in schools, colleges, universities, hospitals and all places of business where computers are used.

- Focus group discussions should be arranged by doctors for the community.

- Awareness of use of protective screens and glasses should be enhanced by using social media, and mass media like newspapers, and electronic media etc.

- Intervention strategies should be devised to increase usage of protective measures in an attempt to decrease the symptoms of CVS in students and increase work efficiency and maintain health

- Different universities should perform similar researches to get a more significant idea of the condition

- CVS should be taken into the account of serious problems in the modern digital world.

\section{Conflict of Interest}

The author declares no conflict of interest related to the study.

Copyright 03 Feb, 2020.

\section{REFERENCES}

1. AlRashidi $S$, AlHumaidan $H$. Computer vision syndrome prevalence, knowledge and associated factors among Saudi Arabia University Students: Is it a Serious Problem. Saudi Arabia: International Journal of Health Sciences; 2017; 11(5): 17-19. Available from: https://www.ncbi.nlm.nih.gov/pmc/ articles/PMC5669505/

2. Randolph S. Computer vision syndrome: Workplace health \& safety. Sage Journals; 2017; 65(7): 328328. Available from: http://journals.sagepub.com/doi/ abs/10.1177/2165079917712727

3. Bogdănici M, Săndulache E, Nechita C. Eyesight quality and computer vision syndrome. Romania: Romanian Journal of Ophthalmology; 2017; 61(2): 112116. Available from: https://www.ncbi.nlm.nih.gov/pmc/ articles/PMC5710018/.

4. Logaraj M, Madhupriya V, Hegde SK. Computer vision syndrome and associated factors among medical and engineering students in Chennai. Chennai: African Journals Online; 2014; 4(2). Available from: https:// www.ajol.info/index.php/amhsr/article/view/112152.

5. Sen A, Richardson S. A study of computer-related upper limb discomfort and computer vision syndrome. J. Human Ergol; 2007; 36(2): 45-50. Available from: https://www.jstage.jst.go.jp/article/ jhe1972/36/2/36_2_45/_article.

6. Porcar E, Pons A, Lorente A. Visual and ocular effects from the use of flat panel displays. Brazil: Int $J$ Opthamol; 2016; 9(6): 881-885. Available from: https:// www.ncbi.nlm.nih.gov/pmc/articles/PMC4916147/. 
7. Jones T. Computer vision syndrome and ergonomic practices among undergraduate university students. Int J ClinPract. 2017; 72(1). Available from: https://doi. org/10.1111/ijcp.13035.

8. Shantakumari N, Eldeeb R, Sreedharan J, Gopal K. Computer use and vision-related problems among university students In Ajman, United Arab Emirate. UAE: AJOL; 2014; 4(2). Available from: https://www.ajol. info/index.php/amhsr/article/view/112242.

9. Noreen Batool Z, Fatima T, Zamir T. Prevalence of computer vision syndrome and its associated risk factors among under graduate medical students; Pak J Ophthalmol. 2016; 32(3): 1-7. Available from: http:// www.pjo.com.pk/32/3/3.\%200A-Khola\%20Noreen.pdf.

10. Mowatt L, Gordon C, Santosh ABR, Jones T. Computer vision syndrome and ergonomic practices among undergraduate university students; Int J Clin Pract. 2018; 28(1). Available from: https://www.ncbi.nlm.nih. gov/pubmed/28980750.

11. Reddy SC, Low CK, Lim YP, Low LL, Mardina F, Nursaleha MP. Computer vision syndrome: A study of knowledge and practices in university students. Nepal J Ophthamol. 2013; 5(2): 161-168. Available from: https://www.ncbi.nlm.nih.gov/pubmed/24172549.

12. Al Tawil L, Aldokhayel S, Zeitouni L, Qadoumi T, Hussein S, Ahmed S S. Prevalence of self-reported computer vision syndrome symptoms and its associated factors among university students. European Journal of ophthalmology, 2018;30(1): 189-195 https://doi. org/10.1177/1120672118815110.
13. Cheema M N, Anwar S2, Afzalnaz M, Saleem A, Nawaz $M$ M. Prevalence of computer vision syndrome and its risk factors among medical students of Islam Medical \& Dental College, Sialkot. P j m h s, Sep 2019; 13 (3,): 553-555.

14. Rosenfield M. Computer vision syndrome: a review of ocular causes and potential treatments. Ophthalmic Physiol Opt. 2011 Sep; 31(5):502-15. doi: 10.1111/j.1475-1313.2011.00834.x. Epub 2011 Apr 12.

15. Khatri A, Kharel R. Knowledge, Attitude and practice of computer vision syndrome among medical students and its impact on ocular morbidity. Journal of Nepal Health Research Council October 2018;16(40): 291-6 doi: 10.3126/jnhrc.v16i3.21426.

16. Dessie A, Adane F, Nega A, Wami S D, Chercos D H. Computer vision syndrome and associated factors among computer users in Debre Tabor Town, Northwest Ethiopia, Hindawi Journal of Environmental and Public Health, Volume 2018:1-8. https://doi. org/10.1155/2018/4107590.

17. Taha MH, Shehzad K, Alamro AS, Wadi M. Internet use and addiction among medical students in Qasim University, Saudi Arabia. Sultan Qaboos Univ Med J. 2019; 19(2):e142-e147. doi:10.18295/ squmj.2019.19.02.010.

18. Patil A, Bhavya, Chaudhury S, Srivastava S. Eyeing computer vision syndrome: Awareness, knowledge, and its impact on sleep quality among medical students. Ind Psychiatry J. 2019; 28(1):68-74. doi:10.4103/ipj.ipj_93_18.

\begin{tabular}{|c|c|c|c|}
\hline \multicolumn{3}{|c|}{ AUTHORSHIP AND CONTRIBUTION DECLARATION } \\
\hline Sr. \# & \begin{tabular}{c} 
Author(s) Full Name \\
\hline 1
\end{tabular} & $\begin{array}{l}\text { Contribution to the paper } \\
\text { Shumaila Humayun }\end{array}$ & $\begin{array}{l}\text { Sole author, selection of } \\
\text { topic designing of work, } \\
\text { literature search, Data } \\
\text { analysis, interpretation, } \\
\text { results, article writing and } \\
\text { submission. }\end{array}$ \\
\hline
\end{tabular}

